\title{
PENGEMBANGAN MODUL MATEMATIKA BERBASIS MATEMATIKA REALISTIK UNTUK KELAS VII SMP SEMESTER I
}

\author{
Witri Lestari' ${ }^{1}$ Sherly Handayani ${ }^{1}$ \\ ${ }^{1}$ Program Studi Pendidikan Matematika FMIPA, Universitas Indraprasta PGRI \\ Jakarta, Indonesia \\ E-mail: witrilestari.unindra@gmail.com
}

\begin{abstract}
ABSTRAK
Tujuan dari penelitian ini adalah untuk mengembangkan suatu desain bahan ajar pembelajaran berbentuk modul yang efektif untuk memfasilitasi proses pembelajaran matematika peserta didik kelas VII SMP Semester I. Modul Matematika ini dibuat berdasarkan hasil analisis kebutuhan terhadap kompetensi matematika yang seharusnya dimiliki oleh peserta didik kelas VII SMP. Alat pengambilan data berupa angket pertanyaan untuk guru sekolah. Prosedur penelitian diadaptasi dari model pengembangan instruksional (MPI) M. Atwi Suparman yang terdiri dari beberapa langkah, yaitu: mengidentifikasi kebutuhan dan menulis tujuan instruksional, melakukan analisis intruksional, mengidentifikasi perilaku dan karakteristik awal peserta didik, menulis tujuan instruksional khusus, menyusun alat penilaian hasil belajar, menyusun strategi instruksional, mengembangkan bahan instruksional, melaksanakan evaluasi formatif. Temuan penelitian yaitu dihasilkan suatu bahan ajar berbentuk modul yang sesuai dengan tujuan pembelajaran matematika peserta didik kelas VII SMP pada semester.
\end{abstract}

Kata kunci: Modul Matematika Realistik, Kelas VII SMP semester I

\begin{abstract}
The purpose of this research is to develop a design teaching learning materials with shaped a effective module to facilitate the learning process of mathematics of the grade 7 th junior high school students at first semester. This math module is based on needs analysis of the mathematical competencies that junior high school students should have. Data collection tools in the form of questionnairesto the school teacher. The research procedure is adapted from an instructional development model by M. Atwi Suparman which consists of several steps, namely identifying needs and create instructional goals, analyze instructional, identifying the behavior and characteristics of the student's beginning, create special instructional goals, set a learning result assessment tool, set a strategy instructional, develop instructional materials, doing formative evaluation. Research findings that are generated a module-shaped instructional material in a accordance with the purpose of learning mathematics of the grade 7 th junior high school students at first semester.
\end{abstract}

Keywords: Module Realistic Mathematics, Grade 7th Junior High School of First Semester. 


\section{PENDAHULUAN}

Pendidikan mengandung makna suatu kegiatan proses pembelajaran yang terencana yang dapat mengaktifkan peserta didik untuk mengembangkan potensi dalam diri peserta didik. Pendidikan akan membuat manusia mengembangkan potensi dirinya sehingga mampu menghadapi setiap perubahan yang terjadi akibat adanya kemajuan ilmu pengetahuan dan teknologi. Alhasil, manusia tersebut akan mampu menciptakan gagasan baru (Nia, Effendi \& Farlina, 2017). Tujuan pendidikan memuat gambaran tentang nilainilai yang baik, luhur, pantas, benar, dan indah untuk kehidupan. Karena itu tujuan pendidikan memiliki dua fungsi yaitu memberikan arah kepada segenap kegiatan pendidikan dan merupakan sesuatu yang ingin dicapai oleh segenap kegiatan pendidikan.

Dalam sistem pendidikan di sekolah, materi pembelajaran telah diramu dalam kurikulum yang akan disajikan sebagai sarana pencapaian tujuan pendidikan. Salah satu materi pembelajaran yang sangat penting untuk dimiliki peserta didik adalah matematika. Matematika merupakan ilmu yang mampu melatih daya analisis dan logika para siswa dengan pola dan aturanaturan yang didefinisikan secara cermat dan akurat sehingga dalam pengaplikasiannya dapat bermanfaat bagi siswa dalam menyelesaikan permasalahan. Menurut Hobri (2008:151), matematika sebagai ilmu dasar memegang peranan yang sangat penting dalam pengembangan sains dan teknologi, karena matematika merupakan sarana berpikir untuk menumbuhkembangkan daya nalar, cara berpikir logis, sistematis, dan kritis.

Menurut Puskur (2002), mata pelajaran matematika perlu diberikan kepada siswa di jenjang pendidikan dasar dan pendidikan menengah untuk mempersiapkan siswa agar sanggup menghadapi perubahan keadaan di dalam kehidupan dan di dunia yang selalu berkembang melalui latihan bertindak atas dasar pemikiran secara logis, rasional, kritis, cermat, jujur, efisien, dan efektif. Dalam tahap perkembangannya, peserta didik tingkat menengah pertama berada pada tahap periode perkembangan yang sangat pesat, dari segala aspek. Dengan mengetahui perkembangan peserta didik pada tingkat menengah pertama maka dapat dipahami mengenai karakteristik mata pelajaran matematika yang termasuk kedalam kelompok mata pelajaran ilmu pengetahuan dan teknologi. Apabila pendidik telah mengetahui karakteristik dan fungsi dari mata pelajaran matematika. Alangkah baiknya jika itu semua diterapkan di lapangan. Artinya, pendidik menerapkan dan melakukan apa yang dimaksud dan dituju dari pembelajaran matematika.

Kenyataannya masih banyak sekolah yang pendidiknya belum seratuspersen melakukan apa yang seharusnya dilakukan oleh pendidik agar peserta didiknya dapat memiliki kompetensinya. Di lapangan, sering sekali penulis jumpai kendala-kendala yang dihadapi dalam proses pembelajaran. Mulai dari pendidik yang tidak selalu hadir dalam setiap pertemuan proses pembelajaran, karakteristik peserta didik yang bervariasi, hingga sumber belajar yang tidak terlalu memadai. Hal inilah yang penulis temukan pada beberapa SMP Swasta di Jakarta. Mengingat pentingnya proses pembelajaran matematika dan setelah melihat kendalakendala yang dihadapi pendidik dalam proses pembelajaran matematika, maka pendidik dituntut untuk mampu menyesuaikan, memilih, dan memadukan model pembelajaran yang tepat dalam setiap pembelajaran matematika.

Proses pembelajaran dapat berjalan secara efektif dan efisien jika menggunakan bahan ajar yang sesuai dengan kebutuhan peserta didik, mendukung kompetensi yang hendak dicapai peserta didik, memiliki uraian yang sistematis, tes yang terstandar serta strategi 

pembelajaran yang cocok bagi peserta didik. Menurut Daryanto (2014:171), bahan ajar adalah segala bentuk bahan yang digunakan untuk membantu pendidik dalam melaksanakan kegiatan belajar mengajar di kelas. Bahan yang dimaksud bisa berupa bahan tertulis maupun bahan tidak tertulis. Salah satu bahan ajar yang dapat digunakan untuk membantu proses pembelajaran adalah modul. Daryanto (2013:9) modul merupakan salah satu bentuk bahan ajar yang dikemas secara utuh dan sistematis, didalamnya memuat seperangkat pengalaman belajar yang terencana dan didesain untuk membantu peserta didik menguasai tujuan belajar yang spesifik. Peserta didik akan mudah memahami suatu konsep jika pengenalan konsep berlandaskan dunia nyata. Pembelajaran matematika berlandaskan dunia nyata disebut juga dengan Pendekatan Matematika Realistik (PMR) atau yang dikenal dengan sebutan Realistic Mathematics Education (RME). Menurut Zulkardi dan Ratuilma (2010) karakteristik dalam Pendidikan Matematika Realistik Indonesia, yaitu menggunakan masalah konteksual, menggunakan model atau jembatan dengan instrumen vertikal, menggunakan kontribusi siswa, interaktivitas, terintegritss dengan topik pembelajaran lainnya. Pendekatan Matematika Realistik ini dipilih dalam penyusunan bahan ajar bertujuan untuk mengkonstruksi konsep matematika yang berasal dari dunia nyata atau informal ke dalam bentuk formal.

Berdasarkan latar belakang yang telah dipaparkan, penulis akan melaksanakan penelitian "Pengembangan Modul Matematika Berbasis Matematika Realistik Untuk Kelas VII SMP”. Adapun rumusan masalah yang akan diteliti adalah "Bagaimana pengembangan modul matematika berbasis matematika realistik yang efektif untuk peserta didik kelas VII SMP Semester I ?”

\section{METODE PENELITIAN}

Jurnal Analisa Vol.4 No.1 Juni 2018: 51-60
Penelitian pengembangan ini dilakukan di SMP Mutiara 2 Jakarta yang bertempat di Jalan Warakas Nomor 3-4 Tanjung Priok, Jakarta Utara. Metode penelitian yang digunakan dalam penelitian ini yaitu penelitian kualitatif berupa penelitian dan pengembangan atau research and development. Produk yang dikembangkan adalah modul matematika berbasis matematika realistik untuk Sekolah Menengah Pertama kelas VII semester I sebagai bahan penunjang belajar matematika peserta didik. Penelitian dan pengembangan dilakukan bertujuan untuk mengembangkan suatu produk dengan memodifikasi produk yang telah ada agar peserta didik dapat melakukan proses pembelajaran mandiri lebih baik dan efektif. Selain itu, penelitian dilakukan untuk menjembatani kesenjangan antara sesuatu yang terjadi dalam penelitian pendidikan dengan praktik pendidikan dan menghasilkan produk penelitian yang dapat digunakan untuk mengembangkan mutu pendidikan.

Pengembangan desain pembelajaran dalam penelitian ini mengacu pada Model Pengembangann Instruksional (MPI) oleh Suparman (2014:116). Pengembangan sistem instruksional adalah suatu proses secara sistematis dan logis untuk mempelajari problem-problem pengajaran, agar mendapatkan pemecahan yang teruji validitasnya dan praktis bisa dilaksanakan. Model ini terdiri dari tiga tahap yang tiap tahapnya memiliki langkah-langkahnya masing-masing, yaitu:

1. Definisi, langkah-langkahnya adalah:

a. Mengidentifikasi kebutuhan instruksional dan menulis tujuan instruksional umum.

Pertama kali yang harus dilakukan ketika mendesain pembelajaran adalah uji kebutuhan belajar. Artinya dalam kegiatan ini perancang instruksional bukan menganalisis apa yang perlu diajarkan tetapi menganalisis apa yang dibutuhkan oleh peserta didik untuk 

dikuasai. Hasil dari kajian ini berupa rumusan kompetensi yang menggambarkan kemampuan yang ingin dikuasai peserta didik. Rumusan kompetensi inilah yang nantinya akan dijadikan tujuan instruksional.

\section{b. Melakukan analisis instruksional.}

Menurut Suparman (2014:177) bahwa "analisis instruksional adalah proses menjabarkan perilaku umum menjadi perilaku khusus uang tersusun secara logis dan sistematis". Kegiatan tersebut dilakukan untuk mengidentifikasi perilaku-perilaku khusus yang dapat menggambarkan perilaku prasyarat, perilaku yang menurut urutan gerakan fisik berlangsung terlebih dahulu atau secara kronologis terjadi lebih awal.

c. Mengidentifikasi perilaku dan karakteristik awal peserta didik.

Pada langkah ini dilakukan kajian mengenai siapa yang akan belajar, yaitu peserta didik. Sebuah desain instruksional dengan tujuan yang sama bisa jadi menerapkan strategi instruksional yang berbeda. Suparman (2014:200) mengemukakan bahwa mengidentifikasi perilaku awal peserta didik dimaksudkan untuk mengetahui siapa kelompok sasaran, populasi sasaran, serta sasaran didik dari kegiatan instruksional. Istilah tersebut digunakan untuk menanyakan peserta didik yang mana atau peserta didik sekolah apa yang seharusnya sudah mereka capai selama mereka mempelajari pelajaran tersebut serta kompetensi apa yang seharusnya sudah mereka capai selama mereka mempelajari pelajaran tersebut.

2. Analisis dan pengembangan prototype sistem, langkah-langkahnya adalah:

a. Menulis tujuan instruksional umum.

Tujuan Instruksional Khusus (TIK) terjemahan dari specific instructional objective. Literature asing menyebutkan pula sebagai objective atau enabling objective untuk membedakannya dari general instructionall objective, goal, atau terminal objective, yang berarti tujuan instruksional umum (TIU) atau tujuan instruksional akhir. TIK dirumuskan dalam bentuk kata kerja yang dapat dilihat oleh mata (observable).

\section{b. Menulis alat penilaian hasil belajar.}

Tes acuan patokan dimaksudkan untuk mengukur tingkat penguasaan da ketercapaian setiap siswa terhadap perilaku yang tercantum dalama TIK.

c. Menyusun strategi instruksional.

Strategi terdiri dari bentuk kegiatan untuk mengawali pembelajaran ata kegiatan pendahulua, model dan metode yang akan digunakan dalam kegiatan inti, bentuk kegiatan latihan, teknik menyampailan umpan balik dan teknik penilaian. Strategi instruksional dalam menyampaikan materi atau isi pelajaran harus secara sistematis, sehingga kemampuan yang diharapkan dapat dikuasai oleh siswa secara efektif dan efisien.

\section{d. Mengembangkan bahan instruksional.}

Dalam tahap ini disusun bahan ajar seperti lembar kegiatan, rangkuman materi ajar, modul belajar, bahan tayang, rekaman suara, multimedia berbasis computer, halaman web dan digunakan tergantung kepada karakter peserta didik, media yang digunakan karakter materi dan kemampuan biaya. Dalam menyusun bahan instruksional, pendesain memperhatikan konteks peyelenggara pendidikan dan bentuk kegiatan instruksional yang akan dilaksanakan. Konteks tempat penyelenggara pendidikan meliputi karakteristik institusi atau organisasi penyelenggara, maksud penyelenggara, sarana dan prasarana kegiatan instruksional, serta segala bentuk kemasan fisik bahan instruksional. 



\section{Melaksanakan evaluasi formatif, langkah-langkahnya adalah:}

a. Penelaahan oleh pakar dan revisi.

Review ini dimaksudkan untuk memperoleh pendapat dari pihak lain sesama ahli tentang berbagai aspek. Pendekatan instruksional membuat instrumen yang berbentuk kusioner, pedoman wawancara dan/tidak cek list sebagai alat observasi sesuai dengan kebutuhan untuk memperoleh informasi.

b. Evaluasi oleh 1-3 peserta didik dan revisi.

Evaluasi satu-satu dilakukan antara pendesain instruksional dengan peserta didik secara individual. Peserta didik yang dipilih adalah yang mempunyai cirri-ciri seperti populasi sasaran. Evaluasi ini dimaksudkan untuk mengidentifikasi dan mengurangi kesalahan-kesalahan yang secara terdapat dalam bahan instruksional dan untuk mendapatkan komentar dari peserta didik tentang tingkat kesulitan dalam memahami isi atau materi instruksional.

c. Uji coba dalam skala terbatas dan revisi.

Evaluasi ini terdiri atas 8-20 orang yang representative untuk mewakili populasi sasaran yang sebenarnya. Maksud sevaluasi keompok kesil ini adalah mengidentifikasi kekurangan kegiatan instruksional setelah direvisi berdasarkan evaluasi satu-satu, baik oleh pakar maupun oleh peserta didik.
d. Uji coba lapangan dengan melibatkan semua komponen dalam sistem sesungguhnya.

Setelah direvisi berdasarkan masukan evaluasi kelompok kecil, produk instruksional tersebut diujicobakan di lapangan sebagai tahap keempat atau tahap akhir dalam evaluasi formatif. Maksud uji coba lapangan ini adalah mengidentifikasi kekurangan produk instruksional tersebut bila digunakan dalam kondisi yang mirip dengan kondisi pada saat produk tersebut digunakan dalam dunia sebenarnya.

\section{HASIL DAN PEMBAHASAN}

\section{Hasil Penelitian}

Hasil penelitian pengembangan ini adalah tersusunnya bahan ajar berupa modul matematika dengan berdasarkan masalahmasalah dalam kehidupan nyata atau realita untuk memfasilitasi peserta didik dalam pencapaian tujuan instruksional umum dan pemecahan masalah sehari-hari serta meningkatkan pemahaman peserta didik. Produk ini memuat materi yang mencakup standar kompetensi materi kelas VII SMP pada semester I serta berisikan contoh persoalan pemecahan masalah dalam kehidupan nyata. Materi yang dimuat dalam modul ini dapat dilihat dalam table berikut:

\section{Tabel 1. Uraian Materi Modul}

\begin{tabular}{ll}
\hline \multicolumn{1}{c}{ Tujuan } & \multicolumn{1}{c}{ Uraian materi } \\
\hline Melakukan operasi & Menyebutkan bilangan bulat. \\
hitung bilangan & Mengidentifikasikan besaran \\
bulat dan pecahan & sehari-hari yang \\
& menggunakan bilangan bulat. \\
& Membuat garis bilangan dan \\
& menentukan letak bilangan \\
& bulat pada garis bilangan. \\
& Melakukan operasi hitung \\
& bilangan bulat. \\
& Menentukan sifat-sifat \\
& perkalian dan pembagian \\
& bilangan bulat. \\
& Menentukan kuadrat dan \\
& pangkat tiga, serta akar \\
& kuadrat dan akar pangkat \\
& tiga. \\
& Menyebutkan bilangan \\
& pecahan. \\
& Menentukan letak pecahan \\
& pada garis bilangan. \\
& Menentukan cara mengubah \\
& bentuk pecahan. \\
& Mencari bilangan pecahan \\
& yang senilai. \\
& Melakukan operasi hitung \\
sifat operasi hitung & bilangan pecahan. \\
&
\end{tabular}




\section{Tujuan \\ instruksional}

bilangan bulat dan pecahan dalam pemecahan masalah.
Mengenali bentuk aljabar dan unsur unsurnya Melakukan operasi pada bentuk aljabar.

Menyelesaikan persamaan linear satu variabel.

Menyelesaikan pertidaksamaan linear satu variabel.

Membuat matematika dari masalah yang berkaitan dengan persamaan dan pertidaksamaan linear satu variabel.

\section{Uraian materi}

Menentukan sifat-sifat operasi hitung pada bilangan

bulat.

Menyelesaikan masalah dengan menggunakan sifatsifat operasi hitung pada bilangan bulat.

Melakukan cara

menggunakan operasi hitung

dalam menyelesaikan masalah sehari-hari yang berkaitan dengan bilangan bulat.

Melakukan cara menggunakan operasi hitung dalam menyelesaikan masalah sehari-hari yang berkaitan dengan pecahan.

Menentukan variabel, konstanta, koefisien, faktor, suku, dan suku sejenis. Melakukan operasi hitung pada bentuk aljabar.

Menggunakan sifat operasi hitung untuk menyelesaikan soal dalam bentuk aljabar. Melakukan operasi hitung pada pecahan untuk menyelesaikan pecahan aljabar.

Mengartikan PLSV dalam berbagai bentuk dan variabel. Menentukan bentuk setara dari PLSV.

Menyelesaikan PLSV untuk mencari penyelesaiannya.

Mengartikan pertidaksamaan linear satu variabel dalam berbagai bentuk dan variabel. Menentukan bentuk setara dri PtLSV.

Menyelesaikan PtLSV untuk mencari akar persamaan.

Menentukan model matematika dari masalah yang berbentuk persamaan linear satu variabel. Membuat model matematika suatu masalah sehari-hari dalam bentuk pertidaksamaan linear satu variabel .

\begin{tabular}{|c|c|}
\hline $\begin{array}{c}\text { Tujuan } \\
\text { instruksional }\end{array}$ & Uraian materi \\
\hline $\begin{array}{l}\text { Menyelesaikan } \\
\text { model matematika } \\
\text { dari masalah yang } \\
\text { berkaitan dengan } \\
\text { persamaan linear } \\
\text { satu variabel. }\end{array}$ & $\begin{array}{l}\text { Menyelesaikan masalah } \\
\text { sehari-sehari yang diubah ke } \\
\text { dalam model matematika } \\
\text { berbentuk persamaan linear } \\
\text { satu variabel. } \\
\text { Menyelesaikan masalah } \\
\text { sehari-sehari yang diubah ke } \\
\text { dalam model matematika } \\
\text { berbentuk pertidaksamaan } \\
\text { linear satu variabel. }\end{array}$ \\
\hline $\begin{array}{l}\text { Mengunakan konsep } \\
\text { aljabar dalam } \\
\text { pemecahan masalah } \\
\text { aritmetika sosial } \\
\text { yang sederhana. }\end{array}$ & $\begin{array}{l}\text { Menentukan cara untuk } \\
\text { nghitung nilai keseluruhan, } \\
\text { nilai per unit, dan nilai } \\
\text { sebagian. } \\
\text { Menentukan cara untuk } \\
\text { menghitung besar laba \& } \\
\text { rugi, persentase laba \& rugi, } \\
\text { harga jual \&beli, rabat, dan } \\
\text { bunga tunggal dalam kegiatan } \\
\text { ekonomi. }\end{array}$ \\
\hline $\begin{array}{l}\text { Menggunakan } \\
\text { perbandingan untuk } \\
\text { pemecahan masalah. }\end{array}$ & $\begin{array}{l}\text { Mengartikan skala sebagai } \\
\text { suatu perbandingan. } \\
\text { Mengidentifikasi faktor } \\
\text { pembesaran dan pengecilan } \\
\text { pada gambar berskala. } \\
\text { Menghitung faktor } \\
\text { pembesaran dan pengecilan } \\
\text { pada gambar berskala. } \\
\text { Mengartikan perbandingan } \\
\text { senilai dan berbalik nilai. } \\
\text { Menggunakan perbandingan } \\
\text { senilai dan berbalik nilai } \\
\text { untuk menyelesaikan } \\
\text { masalah sehari-hari. }\end{array}$ \\
\hline
\end{tabular}

Dalam setiap bab ada penjelasan contoh konsep materi dalam kehidupan sehari-hari. Hal itu terdapat pada kolom 'MATEMATIKA DALAM REALITA' dalam setiap babnya. Tiap sub bab dalam modul matematika ini juga terdapat tugas individu untuk peserta didik, kolom 'AKTIVITAS MANDIRI', yang didasarkan permasalahan nyata dalam kehidupan sehari-hari, sehingga materi yang diberikan dapat lebih dipahami oleh peserta didik. Pemberian latihan soal tiap sub bab tidak hanya disesuaikan dengan permasalahan yang ada dalam kehidupan sehari-hari, tetapi juga diberi soal dengan instruksi yang langsung mengarah pada kompetensi yang ingin dituju. Pada akhir bab juga terdapat evaluasi yang bertujuan agar 
peserta didik dapat terus terlatih menjawab soal-soal pemecahan masalah mengenai materi yang sedang dipelajarinya. Dengan pengerjaan soal-soal dalam bentuk pilihan ganda dan juga esai, diharapkan peserta didik dapat mengerti dan memahami materi yang sudah dipelajari dalam satu bab tersebut. Ada beberapa proses yang harus dilakukan sebelum penyusunan bahan ajar modul matematika ini, yaitu menganalisis kebutuhan instruksional, menentukan tujuan instruksional, melakukan analisis instruksional, mengidentifikasi perilaku dan karakteristik peserta didik, menentukan tujuan instruksional khusus, menyususn alat hasil belajar, menyusun strategi instruksional hingga mengembangkan bahan instruksional.

Dalam mengembangkan modul, hal yang harus dilakukan adalah memilih dan mengumpulkan berbagai bahan instruksional berupa analisis kebutuhan yang dibutuhkan di lapangan, lalu menyusun strategi pembelajaran untuk mengatasi permasalahan-permasalahan yang ada saat melakukan analisis. Selanjutnya pendesain merancang bahan instruksional berdasarkan strategi pembelajaran yang telah dibuat sebelumnya. Pendesain mendesain bahan ajar dengan memperhatikan materi pembelajaran Matematika Sekolah Menengah Pertama kelas VII SMP Semester I. Bahan ajar modul ini terdiri dari 5 Bab yang diadopsi dari kurikulum tingkat satuan pendidikan (KTSP) tahun 2006 sesuai dengan kurikulum yang digunakan oleh tempat penelitian yang pendesain teliti.

\section{Pembahasan}

1. Tahap Pembuatan Modul Matematika

Tahap pembuatan desain pembelajaran yang akhirnya menghasilkan bahan pembelajaran Matematika SMP kelas VII ini dilakukan oleh pendesain diadaptasi dari langkah-langkah model pengembangan instruksional yang dikembangkan oleh $\mathrm{M}$. Atwi Suparman. Adapun tahapan tersebut adalah sebagai berikut.

a. Analisis Kebutuhan dan Menentukan Tujuan Instruksional Umum
Pada tahap analisis kebutuhan, penulis melakukan wawancara serta pemberian angket kepada guru kelas VII SMP, guru les anak kelas VII SMP mengenai karakteristik peserta didik serta kompetensi yang diharapkan dapat dicapai oleh peserta didik yang duduk di kelas VII SMP. Dari kompetensi yang diharapkan dapat dicapai oleh peserta didik kelas VII SMP dirancang Tujuan Instruksional Umum (TIU) untuk menentukan kompetensi-kompetensi yang akan dicapai oleh peserta didik di kelas VII SMP sesuai dengan keinginan dan harapan dari orang tua atau wali peserta didik kelas VII SMP, yaitu "Dengan pemberian soal-soal latihan mengenai materi pelajaran matematika, baik soal cerita tentang realita dalam kehidupan sehari-hari ataupun soal pemahaman konsep yang mengacu terhadap tercapainya kompetensi, diharapkan peserta didik dapat memahami materi yang dipelajari serta mampu menyelesaikan setiap soal secara mandiri, cepat, dan tepat."

b. Analisis Instruksional

Dalam proses pembuatan analisis instruksional sebaiknya memperhatikan struktur-struktur kompetensi, yang terdiri dari struktur hirarkis, struktur prosedural, struktur pengelompokkan dan struktur kombinasi. Keempat struktur ini akan memudahkan dalam penyusunan peta kompetensi yang akan dicapai peserta didik. Penulis membuat sebuah peta kompetensi yang mencakup semua materi yang akan dibahas pada pembelajaran matematika kelas VII SMP.

c. Identifikasi Perilaku Peserta Didik kelas VII SMP

Penulis mengamati perilaku peserta didik yang dapat dilihat dari hasil analisis kebutuhan yang telah dilakukan pada awal kegiatan pengembangan desain instruksional. Hasil dari analisis kebutuhan tersebut dirangkum menjadi perilaku dan karakteristik yang ditunjukkan oleh peserta didik kelas VII SMP.

d. Tujuan Instruksioanl Khusus (TIK)

Perumusan TIK ini sangat tergantung pada TIU. Oleh karena itu, TIU harus 

dimatangkan secara isi. Untuk proses penelitian ini penulis menyusun lima butir TIK yang masing-masing TIK berkaitan dengan TIU yang telah dibuat sehingga mendapatkan komposisi yang pas dan sesuai dengan hasil yang diharapkan.

e. Alat Penilaian Hasil Belajar

$$
\text { Penulis membuat rancangan }
$$

instrumen penilaian yang nantinya akan dijadikan acuan dalam menilai hasil kompetensi pada submateri di setiap bab dan pada akhir pembelajaran Matematika kelas VII SMP. Rancangan instrument yang dibuat oleh penulis berupa butir-butir soal yang akan diujikan pada submateri di setiap bab dan juga akhir proses pembelajaran. Butir-butir soal yang dibuat penulis mengacu pada tabel spesifikasi yang komperehensif.

f. Strategi Pembelajaran

Penulis telah menyusun strategi pembelajaraan ini pada setiap masing-masing TIK dengan dasar TIU. Strategi pembelajarann itu yang nantinya akan digunkan pasa proses pembelajaran di kelas yang dikemas dengan adanya metode dan media pembelajaran hingga alokasi waktu yang ada telah terencana dengan baik. Penulis mengalokasikan waktu selama 40 menit. Dengan strategi pembelajaran ini diharapkan agar setiap tahapan dan pembahasan dalam TIK dapat terlaksana untuk tercapainya kompetensi-kompetensi dalam TIU.

g. Mengembangkan Bahan Instruksional Saat membuat isi muatan buku, penulis mengambil beberapa buku-buku yang digunakan sekolah maupun referensi materi dan soal dari internet untuk dijadikan referensi dalam pembuatan bahan instruksional. Dari segi desain atau tampilan bahan instruksional, penulis membuat semenarik mungkin dengan penggunaan tema atau background dengan warna yang menyejukkan dan mudah diterima oleh peserta didik. Penulis juga menambahkan penjelasan contoh konsep materi dalam kehidupan sehari-hari di setiap babnya, guna menambah daya tarik peserta didik. Hal ini bertujuan agar peserta didik dapat mempelajari setiap materi dari hal-hal yang biasa ditemuinya dalam kehidupan seharihari.

h. Melakukan Evaluasi Formatif

Evalusai formatif yang dilakukan penulis yaitu review oleh para ahli di luar tim pendesain instruksional. Hal ini dimaksudkan untuk memperoleh pendapat dari pihak lain, sesama ahli tentang bagaimana aspek ketepatan konten menurut ahli bidang studi, memadai atau tidaknya strategi instruksional dari pendesain bidang studi, dan desain fisik dari ahli media.

2. Kualitas Modul Matematika Berbasis Matematika Realistik Berdasarkan Para Ahli

Kualitas bahan instruksional Matematika kelas VII SMP didasarkan pada penilaian evaluasi formatif yaitu empat dosen matematika. Komponen penilaian terdiri dari komponen kelayakan isi, komponen kelayakan kegiatan instruksional, dan komponen fisik bahan instruksional. Beberapa masukan yang diperoleh dari empat narasumber berkenaan dengan evalusi bahan instruksional dan proses desain instruksional, yakni sebagai berikut:

Tabel 2. Masukan Evaluasi Formatif dari Para Ahli

\begin{tabular}{|c|c|c|c|}
\hline $\begin{array}{l}\mathbf{N} \\
\mathbf{o}\end{array}$ & & Masukan & Para Ahli \\
\hline 1. & c. & $\begin{array}{l}\text { Penambahan } \\
\text { peta } \\
\text { kompetensi } \\
\text { di setiap bab. } \\
\text { Gambar } \\
\text { background } \\
\text { pada cover } \\
\text { diubah } \\
\text { menjadi lebih } \\
\text { simpel. } \\
\text { Bagian isi bab } \\
\text { tidak perlu } \\
\text { full colour. }\end{array}$ & $\begin{array}{l}\text { Dr. Hasbullah } \\
\text { (Ahli Desain } \\
\text { Gambar dan } \\
\text { Pengembangan } \\
\text { ) }\end{array}$ \\
\hline 2. & a. & $\begin{array}{l}\text { Tambahkan } \\
\text { penjelasan } \\
\text { dan contoh } \\
\text { soal yang } \\
\text { menggunaka }\end{array}$ & $\begin{array}{l}\text { Yogi Wiratomo, } \\
\text { M,Pd. } \\
\text { (Ahli Materi) }\end{array}$ \\
\hline
\end{tabular}




\begin{tabular}{|c|c|c|c|}
\hline \multirow{2}{*}{$\begin{array}{l}\mathbf{N} \\
\mathbf{0} \\
\end{array}$} & & Masukan & Para Ahli \\
\hline & b. & $\begin{array}{l}\text { n matematika } \\
\text { realistik. } \\
\text { Soal latihan } \\
\text { dan evaluasi } \\
\text { harus lebih } \\
\text { banyak yang } \\
\text { berbasis } \\
\text { realistik } \\
\text { daripada soal } \\
\text { konsep. }\end{array}$ & \\
\hline 3. & b. & $\begin{array}{l}\text { Perbanyak } \\
\text { soal } \\
\text { matematika } \\
\text { realistik } \\
\text { karena setiap } \\
\text { bab hanya } \\
\text { terdapat satu } \\
\text { tau dua soal } \\
\text { saja. } \\
\text { Rapihkan } \\
\text { Margin } \\
\text { Perbaiki } \\
\text { tanda } \\
\text { matematika } \\
\text { yang masih } \\
\text { salah. } \\
\text { Penulisan } \\
\text { perhitungan } \\
\text { matematika } \\
\text { dibuat } \\
\text { bersusun ke } \\
\text { bawah, bukan } \\
\text { ke samping. }\end{array}$ & $\begin{array}{l}\text { Indah Lestari, } \\
\text { M,Pd. } \\
\text { (Ahli Materi) }\end{array}$ \\
\hline 4. & $\begin{array}{l}\text { a. } \\
\text { b. } \\
\text { c. }\end{array}$ & $\begin{array}{l}\text { Masih ada } \\
\text { beberapa } \\
\text { huruf yang } \\
\text { kurang/lebih. } \\
\text { Penggunaan } \\
\text { kata hubung } \\
\text { di tengah } \\
\text { kalimat } \\
\text { masih ada } \\
\text { yang kapital. } \\
\text { Penulisan di- } \\
\text { Rata } \\
\text { kanan/kiri } \\
\end{array}$ & $\begin{array}{l}\text { Eka Septiani, } \\
\text { S.S., M,Pd. } \\
\text { (Ahli Bahasa) }\end{array}$ \\
\hline
\end{tabular}

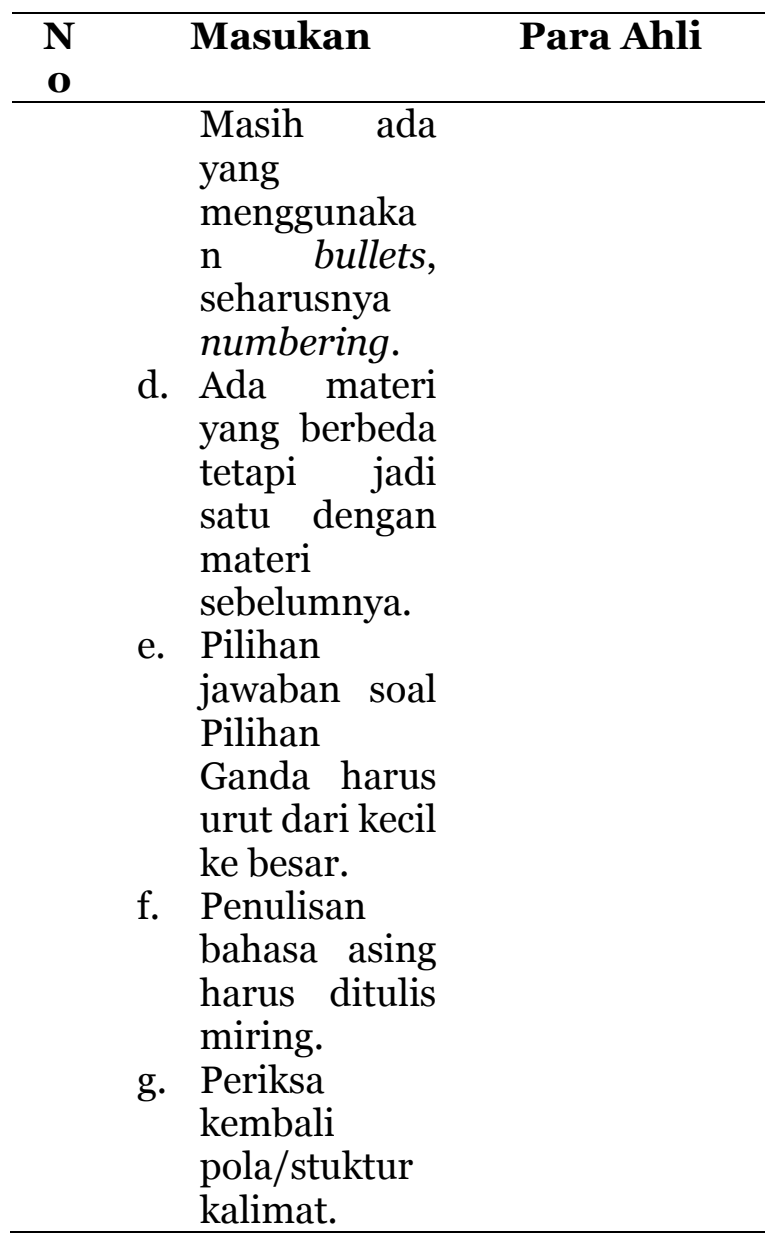

Dalam sebuah buku pasti memiliki kelebihan dan kekurangannya masing-masing, termasuk bahan ajar modul matematika yang penulis kembangkan. Penulis berusaha mendesain cover dengan warna yang tidak terlalu mencolok dan nyaman untuk dilihat, serta gambar cover yang cukup simpel namun tetap dapat menarik perhatian peserta didik untuk membacanya. Di setiap cover bab, ditambahkan beberapa gambar yang berkaitan dengan materi. Peta konsep juga tersedia di lembar terpisah dari cover bab dan juga warna di bagian isi cukup cerah. Dalam pemberian contoh soal dan soal latihan, peneliti memdesain bagian isi agar terdapat lebih banyak konsep matematika realistik. Dengan begitu peserta didik dapat langsung menerapkannya dalam kehidupan seharihari. 
Modul ini juga dilengkapi dengan soal evaluasi yang ada di setiap akhir bab, guna mengukur pemahaman peserta didik mengenai materi yang sudah dipelajari. Dalam penyampaian materipun penulis menggunakan kata-kata yang mudah dipahami oleh peserta didik dan bersifat komunikatif, sehingga diharapkan peserta didik dapat mudah tertarik akan materinya. Dengan segala kemudahan yang disajikan, diharapkan peserta didik mampu memahami pelajaran yang disampaikan oleh guru dengan dibantu modul ini sebagai bahan ajar pendukung.

\section{KESIMPULAN}

Penelitian dan pengembangan ini menghasilkan produk bahan ajar berupa modul matematika berbasis matematika realistik. Pengembangan bahan ajar modul matematika berbasis konsep matematika realistik ini dikembanngkan dengan model pengembangan yang mengacu pada rancangan penelitian dan pengembangan modifikasi dari model pengembangan instruksional atau yang lebih dikenal MPI. Model pengembangan ini merupakan model yang dikembangkan oleh Atwi Suparman. Modul matematika ini dimodifikasi dengan beberapa perubahan dan telah dilakukan evaluasi formatif oleh para dosen ahli di bidangnya masing-masing.

\section{DAFTAR PUSTAKA}

Daryanto. 2013. Menyusun Modul. Yogyakarta: Gava Media.

---. 2014. Pengembangan Perangkat Pembelajaran. Yogyakarta: Gava Media.

Hobri. 2008. Model-model Pembelajaran Inovatif. Jember: Universitas Jember.

Nia, K., Effendi, S., \& Farlina, E. (2017). Kemampuan Berpikir Kreatif Siswa SMP kelas VII dalam Penyelesaian
Masalah Statistika. Analisa, 3(2), 130-137.

Puskur. 2002. Kurikulum dan Hasil Belajar (Kompetensi Dasar Mata Pelajaran Matematika Sekolah Dasar dan Madrasah Ibtidaiyah). Jakarta: Balitbang Depdiknas.

Suparman. 2014. Desain Instruksional Modern Panduan Para Pengajar \& Inovator Pendidikan. Jakarta: Erlangga.

Zulkardi dan Ratuilma. 2010. Pengembangan Blog Support Untuk Membantu Siswa dan Guru Matematika Indonesia Belajar Pendidikan Matematika Realistik Indonesia (PMRI). 